\title{
Ponowoczesne gry w przestrzeni tanatycznej, czyli o zmianach w kulturze pochówku w Polsce
}

\author{
Anna KARNAT*
}

\begin{abstract}
Postmodern games in thanatic space, or changes in the burial culture in Poland: The present article deals with burial culture in Poland and more exactly with its fundamental elements within the context of their permanence and changeability. Beside recourse to the main currents of the discussed publication, the text shows the appearance of new phenomena linked to the formulating anew of the experience of death and its placement within the postmodern landscape, one marked by the high dynamism of processes, fragmentariness, and a dispersal and detachment from traditionalism. Even though burial cultural in Poland is still extremely strongly marked by tradition and is characterised by a significant stability (the permanence of models and schemes), it is possible to notice within it new phenomena that may be directly linked to consumer culture and the global popularisation of these models. Tendencies to search for new forms of rites and the creation of new rituals, which through their nature will correspond to the postmodern experience of death, are becoming stronger. On the one hand, this may point to an overcoming of the experience of a confrontation with death, while on the other, it constitutes an expression of contemporary games in a space designated by Thanatos. One may state that following the emotional neutrality that was characteristic for the objective and rationalised social relations within modernity, postmodernity liberates new possibilities of expression connected with the act of saying one's farewells to a dead person. These may be original and unique at times, other times merely copied and applied as the set models and schemes of the funeral industry. As a consequence the symbolic sphere and some of the rituals accompanying burial allows for the staging of an individual, objective and original burial act on the one hand, while on the other, for a succumbing to commercialisation and entrance into the on-going process of funeral service market-focusing, and of a more economical orientation towards death.
\end{abstract}

\section{KEYWORDS}

funeral rituals; funeral industry; necro-business; commodification of death; a burial

* Dr socjologii, adiunkt w Instytucie Filozofii i Socjologii, Uniwersytet Pedagogiczny w Krakowie. E-mail: annakarnat@gmail.com. 


\section{WPROWADZENIE}

\section{[...] kto nie rodzi wtaśnie się,}

ten już umiera.

Bob Dylan, It's Alright, $M a$

Książka Anny E. Kubiak Pogrzeby to nasze życie (Kubiak, 2015), będąca inspiracją i punktem wyjścia dla niniejszego tekstu, dotyczy bezpośrednio faktu śmierci i życia ze śmiercią. Życia ze śmiercią rozumianą jako wydarzenie, wokół którego narasta przemysł funeralny, ale także szerzej, ze śmiercią uświadamianą jako konieczność w ludzkiej egzystencji. Autorka odsłania wielorakie doświadczenia związane ze zderzeniem człowieka z umieraniem oraz próbuje nakreślić ich kulturowe i społeczne tło. To publikacja wielowątkowa, dająca bardzo szeroki obraz kultury pochówku w Polsce na przestrzeni ostatnich kilkudziesięciu lat oraz opisująca występowanie nowych zjawisk i tendencji w jej zakresie. Sytuuje się na pograniczu socjologii i antropologii kultury, ale odwołuje się również do głębszych odniesień związanych z transcendentalnym kontekstem śmierci. Recenzowana publikacja jest opracowaniem dotyczącym przede wszystkim funkcjonowania branży funeralnej w Polsce, a więc jej profesjonalizacji, urynkowienia, wykształcenia się zawodu przedsiębiorcy funeralnego — pogrzebownika. Odnosi się również, w części wprowadzającej, do funeralnych struktur i modeli wyłonionych za granicą (w Europie i Stanach Zjednoczonych), a mianowicie standaryzacji i demokratyzacji sfery usług pogrzebowych, biurokratyzacji temu towarzyszącej, medykalizacji śmierci i jej monopolizacji przez instytucję szpitala. Większość tych zjawisk, obserwowanych wcześniej w innych krajach, charakteryzuje współcześnie polskie zakłady i przedsiębiorstwa pogrzebowe, wyznaczając ich swoistą historię i przeobrażenia, jakim podlegają. Wcześniej zakłady te miały głównie charakter firm rodzinnych, a obecnie funkcjonują także jako zracjonalizowane i zorganizowane podmioty na rynku usług funeralnych. Sporą część rozważań stanowią opisy składników kultury pochówku, w tym roli Kościoła katolickiego, rodzajów pogrzebów i scenariuszy ceremonii pożegnań (pogrzeby tradycyjne, kremacje, pogrzeby katolickie i świeckie), rytuałów pożegnań, pogrzebów w posttradycyjnym porządku, tak zwanych pogrzebów tematycznych (na przykład motonitów, czyli motocyklistów) czy też wychodzących poza antropocentryczny zakres - pogrzebów zwierząt (pupili domowych).

Tytuł recenzowanej książki autorka zapożyczyła od Konrada Szołajskiego, który wyraził zgodę na wykorzystanie tytułu filmu dokumentalnego w jego reżyserii - Pogrzeby to nasze życie (rok produkcji 2004) ${ }^{1}$. Bynajmniej nie jest to tytuł jednoznaczny. Bezpośrednio odwołuje się do służb i usług pogrzebowych, dla których pochówki są realnym źródłem dochodów, a więc które $\mathrm{w}$ sensie

${ }^{1}$ Film dostępny w sieci: https://www.cda.pl/video/1086501b3 lub: https://www.youtube. com/watch?v=JmWBFocyx1c (dostęp: 01.12.2017). 
dosłownym (finansowym) żyją z pogrzebów. Jego znaczenie jest jednak o wiele szersze i wskazuje na wszechobecność oraz jednocześnie codzienność (powszechność) i niecodzienność (oryginalność) ceremonii pogrzebowych, a także ich sens w życiu jednostek, poszczególnych grup i zbiorowości. Sugeruje też nierozerwalność życia i śmierci oraz wpisanie aktów pochówku w życie codzienne. Śmierć i pochówek są bowiem obok narodzin (oraz ceremonii ślubnych) najbardziej ogniskującą i skupiającą uroczystością, która gromadzi rodzinę, bliskich i znajomych zmarłej osoby. Podkreślenia wymaga fakt, że autorka opiera swoją analizę na bogatych źródłach zarówno zastanych, jak i wywołanych. Dla opisu zmian w szerszym kontekście powołuje się na szereg opracowań naukowych (socjologicznych i antropologicznych oraz filozoficznych), natomiast do pokazania konkretnych zjawisk i nowych elementów w kulturze pochówku wykorzystuje również źródła wywołane oraz pisma i informatory branżowe. Bogaty materiał $\mathrm{w}$ postaci czterdziestu sześciu wywiadów został przez nią zebrany $\mathrm{w}$ różnych środowiskach osób związanych $\mathrm{z}$ przemysłem funeralnym czy też wśród żałobników (ludzi w żałobie). W opracowaniu wykorzystano materiały pochodzące między innymi z wywiadów przeprowadzonych z kierownikami zakładów pogrzebowych, kierownikami krematoriów, mistrzami ceremonii pogrzebowej, organizatorami szkoleń w branży pogrzebowej, zarządcami cmentarzy, reprezentantami firm transportujących zwłoki za granicę, eskortującymi zwłoki, właścicielami zakładów kamieniarskich, duszpasterzem środowisk funeralnych, redaktorem czasopisma funeralnego, osobami w żałobie i innymi.

Do opracowania zebranego materiału i prezentacji konkretnych zjawisk autorka stosuje metodologię opracowaną przez Ervinga Goffmana (Goffman, 2008). Metafora dramaturgiczna pozwala traktować wydarzenia dramatu społecznego jako wyreżyserowany spektakl (teatrum funeralne), z jego aktorami, ze sceną odgrywania ceremonii i kulisami pracy tych, którzy ów spektakl przygotowują (różnorakie działania przedsiębiorców pogrzebowych). Zwłaszcza w przypadku odkrywania tajników zawodu pogrzebownika taka perspektywa umożliwia ukazanie tego, co dzieje się na scenie, a więc podczas rzeczywistego spektaklu i odtwarzania rytuałów związanych z pogrzebem, oraz pozwala unaocznić działania odbywające się za kulisami, a stanowiące zasadnicze przygotowanie do ceremonii i decydujące o jej kształcie. Te ostatnie stanowią dużą część wszystkich zabiegów związanych z pochówkiem. Obejmują bowiem cały zakres działań, które pozwalają doprowadzić do finalnego aktu pożegnania. Składają się na nie: organizacyjne i logistyczne prace przygotowujące scenariusz pochówku, zabiegi związane z przygotowaniem ciała zmarłej osoby (w tym transport zwłok, konserwacja ciała: tanatopraksja — stosowana w Polsce od 1994 roku, i tanatokosmetyka) oraz sfery dekoracyjno-symboliczna (symbole religijne, florystyka funeralna) i informacyjna dotycząca uroczystości pożegnania (ogłoszenia, wydruki pamiątkowych obrazków rozdawanych uczestnikom pogrzebu po uroczystości). „Funeralne widowisko” - jak określa to autorka — jest więc konsekwencją wielu 
poprzedzających go czynności, drobnych i zasadniczych, a także wielu ustaleń, trudnych decyzji podejmowanych przy współudziale rodziny zmarłej osoby. Właśnie te czynności konstytuują treść i przebieg reżyserowanego „widowiska” oraz w dużej mierze decydują o emocjonalnym i estetycznym przekazie, jaki jest udziałem jego uczestników (lub obserwatorów, a w terminologii Goffmana, publiczności). Większość zabiegów, a czasem nawet wszystkie z wymienionych, staje się obecnie przedmiotem działania wyspecjalizowanych firm, których zadaniem jest doprowadzenie do takiego pochówku, jaki jest zgodny z wolą rodziny (z uwzględnieniem ostatniej woli osoby zmarłej).

Warte podkreślenia jest to, że autorka, wychodząc od analizy zebranego materiału badawczego, nakreśla także perspektywy rozwoju i możliwych zmian odnośnie do pogrzebów w XXI wieku. Podkreśla te znaczące przekształcenia, które już teraz widoczne są w branży funeralnej, a mianowicie wzrost zainteresowania kremacją w zastępstwie tradycyjnych pochówków z wykorzystaniem trumien, indywidualne podejście do decydowania o kształcie pogrzebu (własny scenariusz wcześniej wyrażony i przekazany pogrzebownikom przez rodzinę lub przez rodzinę opracowany jako oryginalny i odpowiadający osobowości zmarłej osoby) oraz wzrost estetyzacji ceremonii pochówku. Indywidualizacja ceremonii pogrzebu, jakkolwiek daje się zauważyć, nie jest wiodącym trendem, ponieważ w Polsce stosunkowo utrwalony jest wzór pogrzebu katolickiego, uwzględniający kontekst historyczny i lokalny. Jednak komercjalizacja i globalizacja w tej sferze znajdują swój wyraz w modernizacji usług oraz modyfikacji akcesoriów pogrzebowych (stylistyka trumien i urn, nowoczesne karawany i inne). W bogatej warstwie informacyjnej książki na uwagę zasługuje aneks, załączony po części podsumowującej i bibliografii (Kubiak, 2015: 321-347). Zawiera on nie tylko charakterystykę demograficzno-społeczną badanych respondentów, a więc pracowników branży funeralnej, ale także konkretne dane dotyczące funkcjonujących krematoriów w Polsce (w roku 2014 ich liczba wynosiła trzydzieści) ${ }^{2}$. Poza tym w aneksie zamieszczono skróconą, ale bardzo ciekawą charakterystykę pochówków zróżnicowaną ze względu na region (regionalizacja pogrzebów na mapie województw) oraz dokument — List Episkopatu Polski w sprawie kremacji.

\section{O RODZAJACH POGRZEBÓW I RYTUAŁACH IM TOWARZYSZĄCYCH}

Rytuały są właśnie tym, co czyni z ceremonii pochówku właściwą i określoną uroczystość. Jednocześnie to właśnie one stanowią podstawę dla rozwoju sfery komercyjnej w branży funeralnej, ponieważ mają ścisłe powiązanie z ekonomią ${ }^{3}$.

${ }^{2}$ W roku 2016 było ich już czterdzieści sześć, a kolejnych sześć było w trakcie budowy.

3 W większości przypadków koszt pogrzebu mieści się w granicach udzielanego zasiłku pogrzebowego. Jego wysokość została zmniejszona w 2011 roku, co może powodować rezygnację 
Następuje tu bowiem zagospodarowanie wszelkich możliwych usług świadczonych na rzecz odtworzenia rytualnych czynności oraz proponowanie takich ich dodatkowych elementów, które uzupełniają pochówek tradycyjny i czynią go bardziej uwspółcześnionym, nowoczesnym. Najważniejszy podział w kwestii charakteru pogrzebu i towarzyszących mu rytuatów przebiega na linii: pogrzeb tradycyjny (rozumiany tu jako zorganizowany w konwencji sakralnej, najczęściej katolickiej) oraz pogrzeb świecki. Znaczące różnice dają się zauważyć również z uwagi na wybór rodzaju pochówku; ciało zmarłej osoby w trumnie lub poddane wcześniej kremacji (urna z prochami). Ten drugi rodzaj jest mniej upowszechniony, jednak należy odnotować ciągły wzrost zainteresowania spopielaniem zwłok. W Polsce największy odsetek kremacji w stosunku do wszystkich pochówków (ponad 30\%) ma miejsce w sześciu województwach: zachodnio-pomorskim, pomorskim, mazowieckim, dolnośląskim, łódzkim i śląskim; kremacje sporadycznie odbywają się w województwach: lubuskim, kujawsko-pomorskim, warmińsko-mazurskim, podlaskim, opolskim, świętokrzyskim, lubelskim, małopolskim i podkarpackim. Natomiast województwo wielkopolskie sytuuje się pośrodku, 20-30\% spopieleń. W województwach, w których statystycznie wykonuje się najmniej kremacji, ich liczba może być stosunkowo wysoka lub średnia $\mathrm{w}$ dużych miastach, jednak pozostałe miejscowości i tradycyjne sposoby pochówku rzutują na ogólną statystykę (Kubiak, 2015: 198).

Zachodzenie przemian, jakie towarzyszą sferze śmierci i pochówku w Polsce na przestrzeni ostatnich kilku dziesięcioleci, najbardziej wiązane jest jednak z medykalizacją śmierci. Dzięki rozwojowi medycyny i zinstytucjonalizowaniu aktów śmierci następuje stopniowe i coraz bardziej radykalne zrywanie relacji pomiędzy osobą zmarłą a jej rodziną. Ta, wyraźnie widoczna, separacja żywych i umarłych jest najczęściej powodowana monopolizacją śmierci przez instytucję szpitala (lub hospicjum). Rzutuje to wyraźnie na rytuał przejścia w pochówku sakralnym (katolickim). Trójczłonowa obrzędowość, jaka go charakteryzuje (wyprowadzenie - dom, pożegnanie - kościół, złożenie do grobu - cmentarz) jest nie do utrzymania i została mocno zredukowana, szczególnie jeśli chodzi o pierwszy etap. Najistotniejszym czynnikiem tej zmiany jest właśnie fakt występowania śmierci nie w warunkach domowych, a przeniesienie jej do instytucji (podobnie zresztą dzieje się w przypadku śmierci spowodowanych nagłymi wypadkami i tragicznymi zdarzeniami losowymi). Nawet w przypadku śmierci w środowisku domowym najczęściej następuje szybkie i sprawne zerwanie relacji rodziny ze zmarłą osobą i dzieje się tak nie tylko w miastach. W tym zakresie uwidacznia się obraz zmian związanych z obrzędowością i zwyczajami, ponieważ bezpośrednio po śmierci kontrola nad ciałem zmarłej osoby przejmowana jest przez profesjonalne firmy pogrzebowe. Rytuały odtwarzane na poszczególnych

z niektórych elementów pochówku, a w konsekwencji prowadzić do skromniejszej jego formy. Jednak zdarzają się pogrzeby, których koszt wynosi kilkadziesiąt tysięcy złotych lub więcej. 
etapach przygotowania do pogrzebu odbywają się teraz $\mathrm{w}$ przygotowanych do tego i odpowiednio zorganizowanych zakładach pogrzebowych, które zdają się być połączeniem trzech odrębnych miejsc: domu (miejsca, gdzie tradycyjnie ciato było przechowywane do czasu pogrzebu), kaplicy (rytuały religijne, czuwanie i modlitwy czy chociażby tylko akcesoria i symbole religijne obecne w pomieszczeniu, gdzie znajdują się zwłoki), kliniki (wymagana jest tu odpowiednio wyedukowana kadra w dziedzinie przygotowania ciała zmarłej osoby do ekspozycji). Ten ostatni element, a więc wystawienie ciała na widok obecnych na uroczystości żałobników ciągle postrzegany jest jako nieodzowny element rytuału przejścia

Bez wątpienia większa indywidualizacja w scenariuszu pochówku widoczna jest w odniesieniu do pogrzebów świeckich ${ }^{5}$. Tutaj bowiem nie ma konieczności stosowania się do sakralnej procedury i wiele elementów jest inwencją rodziny lub bezpośrednim spełnieniem ostatniej woli zmarłej osoby. Treść i przebieg obrzędu przejścia prowadzonego przez tak zwanego mistrza ceremonii dostosowuje się do zgłoszonych przez rodzinę próśb, uwzględniając ich duchowe, estetyczne i światopoglądowe potrzeby. Różnorodność form pożegnania może być tym większa, że do tej pory nie wykształcono ujednoliconego wzoru pochówku świeckiego ani nie doprowadzono do wymogu uzyskania urzędowego certyfikatu przez celebranta (Kubiak, 2015: 224). Takie działania, które miałyby unormować swobodną formułę pogrzebu humanistycznego wydają się wręcz niewskazane. Jego istotą jest bowiem oryginalność, podkreślenie podmiotowego traktowania osoby zmarłej, wyjście poza hipokryzję łączoną często z sakralnym pogrzebem „na pokaz”. Indywidualne i wskazane przez rodzinę środki mające na celu pożegnanie osoby zmarłej muszą więc być autentyczne, z nią bezpośrednio związane i podkreślające indywidualność. Trzeba tu zaznaczyć istotną znaczeniowo celowość pochówku sakralnego i świeckiego. Ten pierwszy ukierunkowuje niemal całość obrzędów na osobę zmarłą. Ma jej zapewnić przejście

${ }^{4} \mathrm{~W}$ potocznym podejściu dość silne jest przekonanie, że obecność na pogrzebie równoznaczna jest z zobaczeniem nieboszczyka. Zamknięta trumna (otworzenie jej tylko na ewentualne życzenie rodziny, bez obecności postronnych osób) wywołuje u niektórych „niedosyt” związany właśnie z tym przekonaniem, które łączy fakt zobaczenia zmarłej osoby z jej rzeczywistym pożegnaniem. Wyeliminowanie etapu pożegnania w domu (tak zwane wyprowadzenie z domu) bywa czasami rekompensowane, w sytuacji pogrzebu katolickiego, przez otwarcie trumny w kościele, zanim rozpocznie się właściwa uroczystość religijna. To z kolei może powodować dysonans i spore zaskoczenie u osób, które swojej obecności w kościele w żaden sposób nie łączą z możliwością zobaczenia ciała zmarłej osoby.

${ }_{5}$ Nie ma reguły bez wyjątku. Podczas pogrzebu Wiesława Michnikowskiego (5 października 2017 roku), przy urnie z prochami i portrecie wystawionym przy księdze kondolencyjnej, podczas uroczystości pogrzebowej w jednym z warszawskich kościołów, umieszczono dwa dorodne, dojrzałe pomidory. Skojarzenie było oczywiste dla wszystkich znających artystyczną twórczość zmarłego; swoiste pożegnanie lata (i sezonu pomidorowego) tyle razy przedstawiane przez artystę na scenie, kiedy śpiewał piosenkę zatytułowaną Adios pomidory, zostało tu wykorzystane do ostatniego pożegnania samego wykonawcy. 
do innego „życia”, przenosi w sferę transcendentną. Ten drugi, jakkolwiek służy swojej podstawowej funkcji, to w większej mierze ma na celu celebrowanie przez żałobników przeżytego życia, które już się skończyło. Uroczyste pożegnanie osoby zmarłej pozwala rodzinie uzyskać możliwość powrotu do codziennego życia, zamykając tym samym najtragiczniejszy okres żałoby spowodowany odejściem bliskiej osoby (Kubiak, 2015: 239).

Rytuał pogrzebu, jak zaznacza autorka, został współcześnie rozszerzony na tak zwaną kategorię „nowych zmarłych” (Kubiak, 2015: 247-250). Są nimi płody po poronieniach i aborcjach, którym przyznając status podmiotu, przyznaje się także prawo do godnego pochówku. Ta nowa kulturowa interpretacja jest częścią bardziej złożonych procesów polegających na zmianie roli i znaczenia dziecka $\mathrm{w}$ rodzinie oraz szerzej w społeczeństwie. Zmiany ustawowe w kwestii pochówku obowiązujące w Polsce od 2006 roku tylko częściowo uregulowały postępowanie w takich przypadkach, bowiem stworzenie możliwości pochówku bez względu na czas trwania ciąży nie wytworzyło automatycznie postaw, które odzwierciedlałyby zinternalizowanie nowych norm. Na ten problem nakłada się także ideologizacja problemu w związku ze ścieraniem się orientacji „pro life” oraz środowisk liberalnych. W tę delikatną sferę wkracza także komercjalizacja usług i to zarówno z punktu widzenia zakładów pogrzebowych, jak też instytucji Kościoła.

Nieco innymi prawami rządzą się te ceremonie, które dotyczą zmarłych, którzy za życia zadysponowali swoim ciałem po śmierci i zdecydowali się na donację. Program Świadomej Donacji Zwłok wiąże się bowiem z przeznaczeniem własnego ciała na proces kształcenia dydaktycznego i do badań naukowych. Sentencją, która odzwierciedla sens tego rodzaju zachowania jest: bic est locus ubi mors gaudet succurrere vitae, co znaczy: oto miejsce, gdzie śmierć cieszy sie, $\dot{z} e$ może przyjść z pomoca życiu. Dysponentami są akademie medyczne, które prowadzą działalność propagującą donację w celu pozyskania materiału do prowadzenia doświadczalnych badań i zajęć dla studentów. Możliwość wykorzystania ciała po śmierci zdaje się mieć ogromne znaczenie utylitarne. W tej kwestii zauważyć można znaczący wzrost deklaracji, od kilku rocznie na początku działania programu do kilkudziesięciu obecnie. Przykładowo, baza donatorów na rzecz Akademii Medycznej w Katowicach liczy aktualnie około dziewięciuset zgłoszeń, a ofiarodawcami są już kolejne pokolenia ${ }^{6}$.

\section{O BOHATERZE POCHÓWKU}

Najważniejszym bohaterem ceremonii pochówku jest sama osoba zmarła. Rytuały przejścia dotyczą właśnie jej, a niektóre z nich mają miejsce na etapie

${ }^{6}$ http://natemat.pl/47233,chesz-sie-przydac-po-smierci-przeznacz-zwloki-do-badannaukowych-mamy-cale-rodziny (dostęp: 01.12.2017). 
przygotowania ciała do ewentualnej publicznej ekspozycji ${ }^{7}$. Tutaj nabierają znaczenia określone czynności funeralnych specjalistów, które są z pewnych względów owiane tajemnicą i mogą wydawać się zabiegami magicznymi. Przygotowanie ciała zmarłej osoby do ostatniego spektaklu zostało bowiem usytuowane za kulisami i przejęte całkowicie przez profesjonalistów zatrudnionych w branży. „Humanizacja” zwłok to według autorki książki „proces transgresji trupa w «naszego drogiego zmarłego»” (Kubiak, 2015: 150). Odkrywanie tego, co dzieje się za kulisami, jest jednocześnie ukazaniem rzeczywistego warsztatu pracowników zakładów pogrzebowych, to opis czynności i działań, z których żałobnicy nie do końca zdają sobie sprawę, a których efektem ma być przywrócenie nieboszczykowi ludzkiego oblicza. Wiąże się to również z przywracaniem symbolicznego porządku; tak jak ciału nadaje się jego poprzednią integralność (zachwianą przez akt śmierci), tak przyznaje się siłę tradycji, zapewniając zmarłej osobie godny pochówek. Zgody co do estetyki wizerunku pośmiertnego nie ma. Jednak istnieje przekonanie, że jest on istotny z punktu widzenia najbliższej rodziny. Rytuał ostatniego pożegnania największy nacisk kładzie na twarz i ręce. Przygotowanie ciała oznacza nadanie mu takiego wyrazu, żeby zatrzeć możliwie najmocniej wrażenie oddziaływania śmierci i nadać mu formę wskazującą na przejście do innego świata. Prace nad ciałem mają też praktyczne i symboliczne znaczenie; chronią żałobników przed zanieczyszczeniem i zapachem, swoistym skalaniem w sensie fizycznym i symbolicznym właśnie. Zakres wykonywanych na pośmiertnym ciele prac jest zróżnicowany ze względu na faktyczny stan fizykalny osoby zmarłej, życzenie rodziny, wynikające z zamiaru eksponowania ciała lub nie, wreszcie dostępne środki finansowe. Obejmuje najczęściej czynności związane z toaletą, układaniem ciała, aby znajdowało się ono w pozycji wyrażającej spokojny sen, ubieranie, kosmetykę (różny jej zakres). Należy przy tym podkreślić, że tanatokosmetyka jest silnie rozwijającym się segmentem przemysłu funeralnego.

Generalnie rzecz ujmując, zabiegi te mają na celu utrwalanie określonego obrazu lub opóźnianie rozkładu ciała (konserwacja), ewentualnie przyspieszanie rozkładu, jeśli taki jest kulturowo przyjęty zwyczaj. Pośmiertny makijaż jest stosunkowo powszechny, jednak co do niektórych nowych form działań wobec ciała zmarłej osoby nadal istnieje małe przekonanie czy wręcz opór, także w środowisku samych pogrzebowników. Rodziną zmarłego natomiast powoduje czasem swoisty lęk przed niekontrolowaną ingerencją obcych osób w ciało

7 Znakomitego literackiego opisu rytuałów związanych z ciałem zmarłego dostarcza książka Anny B. Ragde, zatytułowana Ziemia kłamstw (pierwsza część sagi rodzinnej). Autorka jest profesorem antropologii i znaną norweską pisarką. Na użytek literackiej fabuły jednym z bohaterów sagi czyni pogrzebownika, którego pracę opisuje z antropologicznej perspektywy. Natomiast zmiany w samej profesji i nowe tendencje w branży pogrzebowej są przedmiotem opisu w czwartej części sagi, zatytułowanej Zawsze jest przebaczenie. Zob. Ragde, 2011; Radge, 2017. 
ich bliskiego lub wręcz obawy przed jakąś formą profanacji. Tak jest z wizażem, a więc tworzeniem wizerunku osoby zmarłej (Kubiak, 2015: 157). Obejmuje on niemal kompleksowe stworzenie wizerunku człowieka po śmierci, co oznacza dobór uczesania, koloru i kroju ubioru, pełny makijaż, dobór dodatków i ozdób. Tanatopraksja - profesjonalna nazwa dla metod balsamacji - mająca swoją dłuższą historię zarówno w Europie, jak i w Stanach Zjednoczonych, w Polsce pojawiła się wraz z procesami transformacji, w latach dziewięćdziesiątych XX wieku. Wskazuje się na spore korzyści wynikające z jej wykonania, a mianowicie brak stwarzania zagrożenia sanitarnego, epidemiologicznego, zapewnienie tymczasowej konserwacji ciała oraz przywrócenie osobie zmarłej wyglądu przypominającego w dużej mierze jej wygląd za życia ${ }^{8}$. Wykonywanie zabiegów pośmiertnych, o których tu mowa, może wydawać się w społecznym odbiorze czymś nienaturalnym, profanującym sacrum ciała nieboszczyka, czy wręcz zbędnym i niewskazanym. Jednak jest wiele sytuacji, które wskazują na konieczność wykonywania takich zabiegów, aby mogło nastąpić ostatnie pożegnanie rodziny z ich zmarłym bliskim? ${ }^{9}$. Chodzi o liczne przypadki tragicznych śmierci związanych z poważnymi uszkodzeniami ciała, odnajdowaniem zwłok już w stanie poddanym rozkładowi czy zniekształceniem i okaleczeniem ciała w wyniku długotrwałej choroby lub poddawania go zabiegom medycznym o ingerującym charakterze. Stąd współcześnie tanatokosmetykę traktuje się często jako działanie umożliwiające ostatni kontakt rodziny i innych żałobników ze zmarłą osobą. Utrwala się w ten sposób tak zwany portret pamięci, a ostatnie spojrzenie na zmarłego ma dla wielu żałobników ogromne znaczenie. Interesujące jest w tym aspekcie wykorzystanie fotografii (oraz innych form wytwarzania obrazu) do utrwalania pośmiertnego wizerunku ${ }^{10}$. Zdarza się jednak, że nawet osoby spokrewnione (z bliskiej lub dalszej rodziny) odmawiają zobaczenia zmarłego, zwłaszcza jeśli nie uczestniczyły w jego drodze odchodzenia (na przykład związanego z ciężką, wyniszczającą organizm chorobą). Dominuje wówczas stwierdzenie, że w ten sposób chcą zapamiętać osobę zmarłą z czasu

${ }^{8}$ Jakkolwiek tanatoprakterzy funkcjonują w Polsce w liczbie około czterdziestu osób, to sam proces balsamacji jest wykonywany stosunkowo rzadko (jedynie $2 \%$ zmarłych jest mu poddawanych). Ponad czterysta osób ma natomiast warsztatowe i profesjonalne przygotowanie z tanatokosmetyki, która jest stosunkowo rozpowszechniona i proponowana przez większość firm pogrzebowych (Kubiak, 2015: 166-167).

9 Tanatopraksja jest wymagana, gdy chodzi o lotniczy transport zwłok, a w niektórych krajach jest tak również w przypadku transportu naziemnego.

${ }_{10}$ Portret pośmiertny, bo o nim mowa, jest zagadnieniem bardzo szerokim, na które nie ma miejsca w niniejszym tekście. Ma on związek z rozwojem samej fotografii, ale także obrazuje zmiany w kulturze, dotyczące przyzwolenia na wykonywanie i upublicznianie zdjęć zmarłych osób. Także kontekst fotografii rodzinnej unaocznia znaczenie takich pośmiertnych portretów. Szczególnie widoczne jest to w okresie, w którym fotografia była zjawiskiem odświętnym, a sama okoliczność pogrzebu dawała możliwość utrwalenia na zdjęciu członków zebranej rodziny. Często wraz ze zmarłą osobą (tak jak na zdjęciu załączonym do tekstu). 
jej aktywności, jej pełni życia, natomiast bez silnego obrazu martwego ciała, rzutującego później na wcześniejsze wspomnienia.

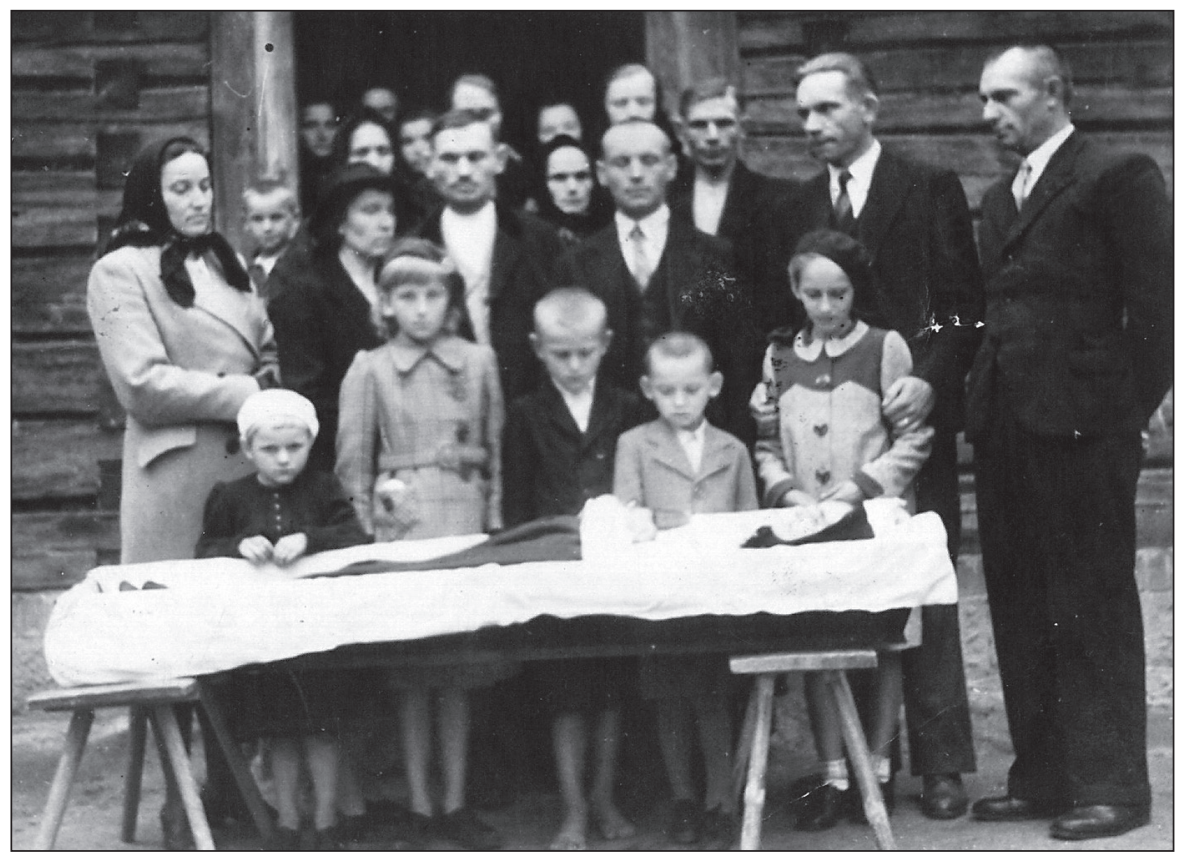

Niektóre elementy ceremonii pożegnania odwołują się do ostatniej woli zmarłego, honorują więc to, co było jego przedśmiertnym życzeniem. Te ostatnie mogą mieć zróżnicowany charakter. Część z nich przybiera widoczną, nawet podkreślaną formę, inne zaś są ukryte i pozostają w sferze intymnych relacji i doświadczeń rodziny ze wspólnego życia z osobą, która odeszła ${ }^{11}$. Do takich należą przedmioty lub inne akcesoria, których chęć posiadania ze sobą po śmierci mogła wyrazić dana osoba jeszcze za życia. Są to różne drobiazgi, przedmioty z życia codziennego, które miały szczególne znaczenie dla zmarłego (obrączka, wieczne pióro, chusteczka, maskotka w przypadku dziecka). Rodzajem osobistego, intymnego pożegnania mogą być także przedmioty, które przez samych bliskich uznane zostały za istotne czy wiążące ich samych w jakimś sensie z osobą, która odeszła. To akt przekazania zmarłemu czegoś ulubionego, dar na drogę $\mathrm{w}$ nieznane, ostatni podarunek. Przedmioty codziennego użytku, w dawnych czasach umieszczane $\mathrm{w}$ grobowcach, zostały współcześnie zminimalizowane co do liczby i ograniczają się do tych wkładanych do trumny (moneta, akcesoria religijne). Nie ma w tym kontekście

${ }^{11}$ Intymność jest tutaj rozumiana szeroko, w znaczeniu, jakie nadał jej Georg Simmel (Simmel, 2005: 97-98). 
koniecznych zachowań (może poza wskazaniami religijnymi), dlatego też pamiątkowe, należące do zmarłych osób rzeczy, których obecność w trumnach potwierdzili pogrzebownicy (rozmówcy autorki książki), to dość długa i urozmaicona lista artefaktów ${ }^{12}$.

\section{PRZEMYSE FUNERALNY I NEKROBIZNES}

$\mathrm{Na}$ zachodzący proces urynkowienia usług pogrzebowych najlepiej wskazuje rozwinięcie się usług w branży funeralnej oraz przejęcie przez profesjonalne firmy pogrzebowe niemal całości przygotowań do ceremonii pogrzebu oraz czynności mających na celu sprawne i odpowiednie jej przeprowadzenie. Monopol Kościoła w zakresie tej sfery został ostatecznie przełamany. Wraz z minimalizowaniem roli rodziny (zwłaszcza na etapie przygotowania zmarłej osoby do pochówku) to właśnie branżowe przedsiębiorstwa działające na rynku mają tu pierwszorzędne znaczenie. Jednocześnie służy to profesjonalizacji i dookreślaniu kategorii zawodowej pogrzebownika. Urynkowienie sfery funeralnej wiąże się z działaniami typowymi dla podmiotów działających na zasadach konkurencyjności, dążenia do zysków, ale także ciągłego podnoszenia jakości swoich usług i profesjonalizacji działań związanych z obsługą pożegnań. Służą temu określone strategie reklamowe, wymiana informacji i kontaktów branżowych, propagowanie nowinek i stosowanie różnego rodzaju zachęt dla klientów. Rozwój swoistego przemysłu w tej branży widoczny jest wyraźnie, jeśli przeanalizuje się zakres usług oferowanych wokół aktu śmierci i pochówku. Wskazać tu można, na przykład, prowadzenie cmentarzy i obiektów do spopielania zwłok, wykonywanie grobów i pomników nagrobnych, działanie domów pogrzebowych, szeroko rozumiane akcesoria pogrzebowe - trumny, sarkofagi, różne rodzaje urn, środki do transportu zwłok i same czynności transportowe (w kraju i spoza jego granic), odzież dla pracowników cmentarzy, mistrzów ceremonii, żałobników i samych zmarłych, środki do balsamacji zwłok i tanatokosmetyki oraz szkolenia specjalistów w tym zakresie, znicze, świece, konkretne usługi pogrzebowe, usługi poligraficzne - klepsydry, wstęgi na wieńcach, zawiadomienia, obrazki pamiątkowe, foldery i katalogi, usługi florystyczne, prowadzenie i oprawę ceremonii pogrzebowych, systemy techniczne i technologiczne potrzebne do wykonywania spopielania zwłok i budowy krematoriów, urządzenia i systemy informatyczne do ich obsługi, urządzenia monitorujące emisję spalin, oprogramowania do obsługi zakładów pogrzebowych i krematoriów. Ostatnie, VII Międzynarodowe Targi Branży Pogrzebowej i Cmentarnej NECROEXPO, największe w Europie Środkowo-Wschodniej, które odbyły się w Kielcach

12 Autorka książki wymienia: krzyżówki, kapelusz, długopis, perfumy, grzebień, lusterko, papierosy, telefon komórkowy, okulary, listy, szalik kibica klubu sportowego, laskę i inne (Kubiak, 2015: 145-146). 
2-4 czerwca 2017 roku, są najlepszym dowodem na wysokie wyspecjalizowanie się, urynkowienie i komercjalizację branży funeralnej ${ }^{13}$. Szeroki zakres tej imprezy wskazuje na wzrost zainteresowania inwestowaniem w sferę funeralną oraz jest świadectwem konkurencji wśród podmiotów oferujących usługi pogrzebowe. Istnieje tu chęć pozyskania klientów jak w przypadku każdego innego rodzaju działalności rynkowej, a przykładem ważności poszukiwania nowych form docierania do ustugobiorców są nagrody przyznawane za innowacyjność w sposobach przyciągania ich do swoich firm. Mowa tu więc o swoistym marketingu funeralnym ${ }^{14}$. Warto zauważyć, że Polska jest największym producentem trumien w Europie i eksportuje je do wielu krajów, stąd też popularyzacja spopielania zwłok jest poniekąd działaniem zawłaszczającym tę sferę, przez długi czas tradycyjnie i jednoznacznie przypisaną do pogrzebu ${ }^{15}$. Podkreślić więc należy zmiany w sposobie pochówku oraz ich ciągłe dostosowywanie się do potrzeb rynku i uwarunkowań kulturowych. Jeżeli nie następuje rytualne złożenie do grobu, to ceremonia pożegnania może odbywać się na przykład na wodzie. W Polsce istnieje zakaz rozsypywania prochów na terenie gruntów, lecz prawnie dopuszczalny jest pochówek w warunkach wodnych. Producenci oferują już urny nowego rodzaju, które wykorzystywane są w takich przypadkach; zrobione są one w taki sposób, że utrzymują się na wodzie, a po niedługim czasie nikną w głębi akwenów wodnych. Różnorodność form, materiału i kolorystyki urn wydaje się nie mieć ograniczeńn ${ }^{16}$.

Oprawa rytuałów pogrzebowych wymaga odpowiednich środków transportu. Nie chodzi tylko o transport zwłok z miejsca śmierci do zakładu pogrzebowego czy specjalistycznego prosektorium, lecz przede wszystkim o samochody używane podczas ceremonii pogrzebu. Zyskały one na znaczeniu w związku z odchodzeniem od tradycyjnie utrwalonych pieszych konduktów

${ }^{13} \mathrm{http}: / /$ targikielce.pl/pl/vii-miedzynarodowe-targi-branzy-pogrzebowej-i-cmentarnejnecroexpo,11934/zakres-branzowy,11935.htm (dostęp: 01.12.2017).

$14 \mathrm{~W}$ tej dziedzinie na wspomnianych targach nagrodę otrzymały między innymi zakłady pogrzebowe z Warszawy i Częstochowy za zorganizowanie dni otwartych w funkcjonujących na terenie tych miast krematoriach. Celem tej akcji było oswajanie opinii publicznej ze spopielaniem zwłok jako możliwym scenariuszem oraz propagowanie tego rodzaju pochówku jako bardziej nowoczesnej formy (również mniej kosztownej i bardziej ekologicznej).

15 Istnieje oczywiście zapotrzebowanie na trumny używane w procesie kremacji, jednak są one innego rodzaju niż te, które eksponowane są podczas pochówku, kiedy spopielenie nie miało miejsca. W jakimś sensie można też stwierdzić, że urny nie stanowią konkurencji dla trumien, ponieważ narasta zainteresowanie nowoczesnymi i zmodernizowanymi ich formami, które stają się wręcz modne i są bardzo drogie. Na przykład trumna metalowa z zewnętrzną mahoniową powłoką, wyposażona w system elektroniczny i odbiornik radiowy, na wypadek pochówku osoby w śpiączce (Kubiak, 2015: 103). Różne typy trumien podlegają również pewnym modom, a ich poszczególne modele nagradzane są na cyklicznych targach (trumna canoe). Inne przykłady to trumny bolid i copula.

${ }_{16} \mathrm{Na}$ targach we Włoszech zaprezentowano urny w kształcie piłek futbolowych, piłek do koszykówki czy rugby. 
i wykorzystania karawanów konnych ${ }^{17}$. Do przydomowych muzeów prywatnych firm pogrzebowych trafiły karawany poruszane przez zaprzęg konny, zwykle czarne, oszklone, z dość bogatą ornamentyką. Zresztą samochód-karawan $\mathrm{w}$ jego poprzedniej formie również odchodzi do przeszłości. Obecnie panują w tej kwestii pewne mody, a generalnie dąży się do jak największej automatyzacji, ułatwienia transportu i wysokiej estetyki. Wyposażenie samochodów staje się uniwersalne, a przynajmniej dwufunkcyjne, to znaczy przystosowane zarówno do przewozu trumien, jak i urn. Nie ma już także obowiązującej kolorystyki, a z pewnością czarna przestała być dominująca ${ }^{18}$. Trzeba zaznaczyć, że nie jest to tylko odejście od kulturowo utwierdzonego koloru żałoby. Ta zmiana znamionuje olbrzymi przeskok (dokonany jednak w sposób stopniowy) od czarnego karawanu konnego do białego samochodu wyposażonego w odpowiednie akcesoria. Na wspomnianych już targach w Kielcach zaprezentowano luksusową limuzynę marki Jaguar, która jest nie tylko wyrazem znaczących przemian w przemyśle pogrzebowym, ale także silnego różnicowania się statusu społecznego i wzrostu znaczenia podziałów $\mathrm{w}$ dostępie do usług pogrzebowych (w dużej mierze wyznaczonych przez zasoby finansowe rodziny zmarłego).

Do nekrobiznesu zalicza się firmy florystyczne, które dbają o elementy dekoracyjne podczas pogrzebu. Oprawa estetyczna zyskuje na znaczeniu, coraz bardziej ceni się wyrafinowany sposób ozdabiania urn, trumien czy wytwarzania wieńców ${ }^{19}$. W dążeniu do nowych estetycznych rozwiązań w wielu przypadkach odchodzi się od sztucznych dekoracji, które uznawane są za mało eleganckie i tanie. Florystyka funeralna przechodzi duże zmiany, a firmy pogrzebowe korzystają z wyspecjalizowanych florystów. Nowo upowszechniającym się zwyczajem jest rezygnowanie z przynoszenia na pogrzeb wiązanek i kwiatów przez żałobników luźniej związanych ze zmarłą osobą. W zamian za to, zgodnie z wolą zmarłej osoby lub na życzenie jej rodziny, przeprowadza się zbiórkę pieniędzy na określony cel, na przykład wsparcie działalności fundacji lub jakiejś organizacji pożytku publicznego (często są to hospicja i domy pomocy dla osób terminalnie chorych, ale również organizacje działające na rzecz dobrostanu zwierząt).

${ }^{17}$ Dla przykładu, w Żywcu burmistrz zakazał konduktów pieszych, natomiast w Bielsku-Białej nadal organizuje się je (Kubiak, 2015: 340).

${ }^{18}$ Dobrą ilustracją jest tu pewna firma pogrzebowa z Wrocławia, która dysponuje jedynie białymi samochodami do transportu zwłok.

19 Dla przykładu na zdjęciach i filmach z pogrzebu Elvisa Presleya (18 sierpnia 1977 roku) widoczne były wieńce w kształcie gitary, wykonane z samych kwiatów. Na pogrzebie polskiej artystki estradowej Hanny Bielickiej (6 marca 2006 roku) na trumnie umieszczony był wieniec w postaci kapelusza, „kwietny kapelusz” — jak prezentowały to portale internetowe. Był to znak rozpoznawczy artystki i jej atrybut sceniczny. 


\section{PONOWOCZESNE GRY}

Ponowoczesność wnosi do teatrum funeralnego w Polsce niespójne tendencje. $\mathrm{Z}$ jednej strony, rośnie znaczenie podmiotowego, zindywidualizowanego traktowania bohatera pochówku, a z drugiej, komercjalizujący się i wyspecjalizowany nekrobiznes proponuje gotowe wzory, kopie zachowań już wykształconych wcześniej w kulturze Zachodu. Jednocześnie można zauważyć bogatą oprawę, estetyzację i przepych obrzędu pogrzebowego oraz dążenie do prostoty, ekologicznego myślenia, swoistego minimalizmu. Daje się również zauważyć wchodzenie $\mathrm{w}$ sferę funeralną nowych technologii oraz mediatyzacja pochówków, co sprzyja przenoszeniu wzorów, upowszechnianiu nowinek i zmianie tradycyjnych form ${ }^{20}$. Nowym technologiom daje się zawładnąć także sam obrzęd pogrzebu. Należy tu wymienić relacje on-line, przekazy multimedialne, profesjonalne sesje fotograficzne relacjonujące przebieg uroczystości.

Podkreślenie podmiotowości i decydowania o sobie, tak istotne w wysoko rozwiniętych społeczeństwach, w kontekście pochówku zaznacza się indywidualizacją potrzeb na określone usługi, staje się materiałem do wykorzystania w kampaniach marketingowych dla przedsiębiorstw funeralnych i w konsekwencji nie pozostaje bez znaczenia dla zachowań utrwalonych w tym zakresie tradycją. Ponowoczesne uwolnienie ekspresji i wyjście ze zracjonalizowanych wzorów mają przełożenie na niemal wszystkie etapy przygotowania uroczystości pogrzebowej, odtwarzania charakterystycznych dla niej obrzędów (samego spektaklu), a także sposobu przeżywania żałoby. Nadając tym bogatszą oprawę rytuałowi przejścia, w coraz mniejszym stopniu zaznacza się widoczne oznaki żałoby po ceremonii pogrzebu. Kolor czarny stosowany w ubiorze przestał być obowiązującą normą, widocznym wskaźnikiem faktu odejścia kogoś z bliskich. Trudno już także zauważyć kiry (czarne tasiemki czy wstążki o różnej szerokości) noszone dla oznaczenia żałoby na wierzchnich ubraniach (rękawy płaszczy i żakietów, klapy marynarek). Okres symbolicznego (czarny ubiór) okazywania przeżywanej żałoby również został skrócony. Z pewnością nie obejmuje jednego roku, jak było to $\mathrm{w}$ Polsce jeszcze w latach siedemdziesiątych XX wieku, kiedy w wielu mniejszych miejscowościach i środowiskach wiejskich stosowano go dokładnie tak długo. Czas przewidziany na noszenie zewnętrznych oznak żałoby był zresztą dość ścisłe zwyczajowo określony i zróżnicowany z uwagi na stopień pokrewieństwa z osobą zmarłą.

Przejmując kontrolę nad własnym życiem, jednostka w ponowoczesności zmuszona jest do określenia siebie $\mathrm{w}$ czasie, stąd uwidaczniające się tendencje do planowania pogrzebu, które nie ograniczają się tylko do podstawowych

${ }^{20}$ Autorka wskazuje na „pogrzeby smoleńskie”, które w społecznym odbiorze stały się istotnym wyznacznikiem sposobu celebrowania ostatniego pożegnania. Znacząco zmieniły się oczekiwania klientów, idąc w stronę elegancji czy nawet przepychu (Kubiak, 2015: 78, 241-244). 
wyborów, zamkniętych w haśle „ostatnia wola”. Decyzje nie dotyczą już tylko rodzaju pogrzebu i charakteru pochówku. Dominujący w Polsce charakter katolickiej ceremonii poddany został profesjonalizacji i ustandaryzowaniu dzięki współczesnym firmom pogrzebowym, które przejęły niemal pełną kontrolę nad przygotowaniem uroczystości (w niektórych przypadkach przedstawiciele firm zastępują nawet bezpośredni kontakt rodziny zmarłego z osobą duchowną, jeśli ta daje na to przyzwolenie). Trzeba jednak zaznaczyć, że w Polsce elementy ponowoczesne koegzystują z mocno utrwalonymi tradycyjnymi, a w niektórych przypadkach także archaicznymi obyczajami i wierzeniami o regionalnym charakterze. Znaczącym rysem jest $\mathrm{z}$ pewnością widoczne przesunięcie $\mathrm{w}$ stronę upublicznienia ceremonii. I nie chodzi tu tylko o pochówki znanych, publicznych osób, którym nadaje się medialny charakter. Upublicznienie śmierci związane jest bezpośrednio z eliminacją tej sfery ze środowiska domowego, medykalizacją śmierci i niebezpiecznym mariażem instytucji szpitala z przedsiębiorstwem pogrzebowym. Natomiast ponowoczesne nakładanie się sfer prywatnej i publicznej widoczne jest w przypadku prób odgradzania się osób publicznych od obecności mediów i przechodzenia w stronę prywatnych ceremonii ${ }^{21}$.

Przeformułowanie usług funeralnych w model przemysłowy, w swoisty nekrobiznes oraz komercjalizacja tej sfery dają z jednej strony poczucie uwolnienia od obowiązków wcześniej przypisanych do rodziny zmarłego, a z drugiej czynią z żałobników konsumentów decydujących o kształcie pochówku i dokonujących wyborów wedle własnych gustów oraz posiadanych zasobów finansowych. Nowinki w postaci wirtualnych memoriałów, mikrochipów z zakodowanymi informacjami o zmartym (montowane na nagrobkach), wykorzystanie multimediów, wykonywanie „diamentów pamięci” (z prochów lub włosów) czy też zastosowanie innych nieznanych dotąd akcesoriów (baldachimów, urn wodnych) mają już miejsce i współegzystują z tradycyjnymi elementami kultury pochówku. Następuje nakładanie się globalnie przenoszonych wzorów i lokalnie utrwalanych tradycji - to funeralna glokalizacja. Dla przykładu tryzna - okolicznościowa zabawa towarzysząca pogrzebom w polskiej kulturze ludowej przeistoczyła się w ponowoczesny mariaż kultury pochówku i wszechobecnej kultury konsumpcji, dając wyraz komercjalizacji (i ekonomizacji) nieodzownej strony życia, jaką jest śmierć.

Widoczne jest również umacnianie się wpływu kultury obrazkowej. Stosunkowo szybko rozpowszechniło się w Polsce umieszczanie zdjęcia przy szczątkach zmarłej osoby. Zdjęcie znajduje się przy trumnie lub urnie i nie ma znaczenia czy ceremonia ma charakter sakralny (w budynku kościoła) czy też świecki (dom pogrzebowy, dom pożegnań). Portret najczęściej przenoszony jest na

${ }^{21} \mathrm{~W}$ przypadku osób znanych, celebrytów i artystów ze świata popkultury uwidacznia się organizowanie zdublowanych ceremonii; prywatnych (poza kontaktem z mediami), w których uczestniczą tylko osoby najbliższe, oraz publicznych, w których dopuszcza się udział osób niezwiązanych bezpośrednio z osobą zmarłą (fani, miłośnicy). 
miejsce pochówku przez obsługę ceremonii lub przedstawiciela rodziny i po uroczystości pogrzebowej zabierany do domu jako pamiątka. Ten wizualny akcent znajduje już swoją nowszą wersję, ponieważ niektóre z firm pogrzebowych idą w tej kwestii jeszcze dalej i proponują w domach pogrzebowych możliwość wyświetlania zdjęć jako oryginalną formę pożegnania przed aktem pochówku (na przykład multimedialna sala pożegnań w Rudzie Śląskiej). Zgromadzone podczas ceremonii osoby mają okazję przypomnieć sobie (lub być może po raz pierwszy zobaczyć) drogę życia i fakty z biografii zmarłej postaci, przekazane w obrazach, zdjęciach czy nawet krótkich filmach. Warto podkreślić, że zwyczaj eksponowania zdjęcia zmarłej osoby początkowo dotyczył jednostek powszechnie znanych, jednak obecnie spopularyzowat się i praktykowany jest nie tylko w miastach, ale także małych miejscowościach i wsiach. Innym przykładem mediatyzacji są bezpośrednie transmisje telewizyjne i internetowe ceremonii pogrzebów lub umieszczanie w sieci filmów z ich przebiegu. Dotyczy to zwłaszcza pochówku osób znanych, popularnych, ale może dotyczyć także tych, których śmierć z jakichś względów uległa mediatyzacji i upublicznieniu, a tym samym zaabsorbowaniu nią opinii publicznej.

\section{ZAKOŃCZENIE: ŚMIERĆ - CIĄGLE ŻYWY TEMAT}

Anna E. Kubiak pisze: „Stosunek do śmierci określa również stosunek do życia zarówno w wymiarze jednostkowym, jak i narodowym" (Kubiak, 2015: 10). Podobny wyraz ma stwierdzenie, jakie stało się motywem przewodnim wizyty w Polsce francuskiego filozofa i pisarza Erica-Emmanuela Schmitta. Podczas pobytu w Krakowie, na 26 Międzynarodowych Targach Książki w 2017 roku, powiedział, że „Rozmawiać o śmierci znaczy: umieć życ” ${ }^{\prime 22}$. Rozmowy o śmierci są w gruncie rzeczy wielowątkowe, ponieważ nie muszą dookreślać jedynie tego, co wiąże się z faktem śmierci każdego człowieka i jego decyzjami co do obrzędu przejścia. Mogą dotyczyć socjalizacji do śmierci (na różnych etapach życia ludzkiego), podstawowego uświadamiania sobie jej istnienia i prób zrozumienia sensu. Mówić o niej można lub nie wypada w sytuacji choroby (na przykład trudna komunikacja lekarzy z osobami terminalnie chorymi lub ich bliskimi). Skoncentrowanie w omawianej książce uwagi na tych, którzy obcują ze śmiercią na co dzień, dało wynik niezwykle intersujący. Radzenie sobie z ciągłym doświadczaniem śmierci przez pracowników firm pogrzebowych pokazuje jak wielki ciężar i jednocześnie odpowiedzialność spoczywają na tych, którzy czynią funeralny spektakl możliwym. Przejście do profesjonalnych

\footnotetext{
${ }^{22}$ http://gosc.pl/doc/4274847.Eric-Emmanuel-Schmitt-Rozmawiac-o-smierci-znaczyumiec-zyc (dostęp: 01.12.2017). Omawianej tu problematyce poświęcone są następujące, godne polecenia publikacje: Bauman, 1996; Bauman, 1998; Bauman, 2006; Bauman, 2012; Clark, 2000; Hitchens, 2013; Karnat-Napieracz, 2008; Le Callet, 2015.
} 
usług z jednoczesnym ukierunkowaniem na emocjonalną empatię często jest nie do pogodzenia, a na pewno stanowi ogromne wyzwanie dla pracowników sfery funeralnej. Mają oni bowiem kontakt z członkami rodzin pozostającymi w dramatycznej sytuacji po stracie najbliższych osób, a jednocześnie w sytuacji konieczności zorganizowania i uczestniczenia w finalnym akcie pożegnania. Goffmanowska metafora teatru, zastosowana do analizy, odkrywa tajniki zawodu pogrzebownika, ale tym samym zapoznaje czytelnika z zachodzącymi zmianami i przynosi wiele cennych informacji. Pogrzebownicy redefiniują swój zawód i pozycję w społecznej strukturze, a ujawniając kulisy swojej profesji, propagują określoną wiedzę, oswajają z nowymi elementami kultury pochówku i być może uczą rozmawiać o śmierci.

\section{BIBLIOGRAFIA}

Bauman, Z. (1996). Ponowoczesność, czyli dekonstruowanie nieśmiertelności (s. 143-167). W: S. Czerniak \& A. Szahaj (Red.). Postmodernizm a filozofia. Wybór tekstów. Warszawa: IFiS PAN.

Bauman, Z. (1998). Śmierć i nieśmiertelność. O wielości strategii życia. (Przet. N. Leśniewski). Warszawa: Wydawnictwo Naukowe PWN.

Bauman, Z. (2006). Społeczeństwo w stanie oblężenia. (Przeł. J. Morgański). Warszawa: Wydawnictwo Sic!

Bauman, Z. (2012). To nie jest dziennik. (Przet. M. Zawadzka). Kraków: Wydawnictwo Literackie.

Clark, W. R. (2000). Pteć i śmierć. (Przeł. A. Alichniewicz \& A. Szczęsna). Warszawa: Państwowy Instytut Wydawniczy.

Goffman, E. (2008). Człowiek w teatrze życia codziennego. (Przeł. H. Datner-Śpiewak \& P. Śpiewak). Warszawa: Aletheia.

Hitchens, Ch. (2013). Śmiertelność. (Przet. R. Madejski). Katowice: Wydawnictwo Sonia Draga.

Karnat-Napieracz, A. (2008). Śmierć i nieśmiertelność w ponowoczesności. Kilka uwag w kwestii Baumanowskiego konstruktu tożsamości indywidualnej (s. 201-213). W: I. Jeziorski \& M. Korzewski (Red.). Eros - Patos - Thanatos. Świat(y) wartości spoteczeństwa polskiego u progu XXI wieku. Bielsko-Biała-Żywiec: Towarzystwo Naukowe Żywieckie.

Kubiak, A. E. (2015). Pogrzeby to nasze życie. Warszawa: Wydawnictwo IFiS PAN.

Le Callet, B. (2015). Marzenia wykute w kamieniu. (Przet. B. Sęk). Katowice: Wydawnictwo Sonia Draga.

Ragde, A. B. (2011). Ziemia kłamstw. (Przeł. E. M. Bilińska). Sopot: Smak Słowa.

Ragde, A. B. (2017). Zawsze jest przebaczenie. (Przet. E. M. Bilińska \& K. Drozdowska). Sopot: Smak Słowa.

Simmel, G. (2005). Socjologia. (Przeł. M. Łukasiewicz). Warszawa: Wydawnictwo Naukowe PWN.

Wykorzystane zdjęcie z archiwum prywatnego:

Pogrzeb we wsi Grębów (Podkarpacie); datowany na kwiecień 1945 roku. 
